\title{
A Companion to Medieval Palermo
}

\author{
The History of a Mediterranean City \\ from 600 to 1500
}

\author{
Edited by \\ Annliese Nef \\ French and Italian texts translated by \\ Martin Thom
}

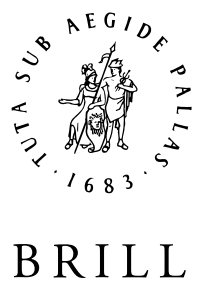

LEIDEN • BOSTON

2013 


\title{
PALERMO IN THE 14TH-15TH CENTURY: THE URBAN SOCIETY
}

\author{
E. Igor Mineo
}

\section{Introduction. The Formation of a New Community at the END OF THE 13TH CENTURY}

The chronological limits of this essay cannot be fixed with absolute precision, since they are determined by the type of perspective we choose to adopt regarding the "social" world of a great city. Our point of departure is, however, traditional. Despite the new lines of enquiry developed over the last twenty-five years, the Vespers, which by tradition serve to cut Sicilian history in two (before and after 1282), help us to impose order upon the phenomena with which we are concerned. Our destination is far less easy to pin down, and we therefore need to identify more than one: 1392, and the restoration of royal rule, and 1516, which saw the death of Ferdinand the Catholic (and the definitive, though very troubled, passage to a new, wholly "Spanish" epoch), are dates of crucial importance for the entire island; as was $145^{\circ}$ for the capital, on account of a revolt that reveals much about the social geography of the city midway through the $15^{\text {th }}$ century.

The social processes that interest us here were not of course determined by the Vespers as such, indeed some important preconditions had been established earlier. In the latter half of the 13th century two discontinuities in the institutional context had occurred. We cannot tell exactly when, although it was probably after the middle of the century, the text of the customs was drafted, as a system of rules in some way produced by the community; ${ }^{1}$ later, in the Angevin period, a tendency arose, which after 1282 would become irreversible, to elect the city's officials and not to have them be appointed by the royal court. ${ }^{2}$ We are concerned here with

1 The texts were edited, with a commentary, by Vito La Mantia, Antiche consuetudini delle città di Sicilia (Palermo, 190o); see Ennio Igor Mineo, "Norme cittadine, sviluppo istituzionale, dinamica sociale: sulla scritturazione consuetudinaria in Sicilia tra XIII e XIV secolo," in Gabriella Rossetti, ed., Legislazione e prassi istituzionale nell'Europa medievale. Tradizioni normative, ordinamenti, circolazione mercantile (secoli XI-XV) (Naples, 2001), pp. 341-61.

2 Fabrizio Titone, Governments of the "Universitates": urban communities of Sicily in the fourteenth and fifteenth centuries (Turnhout, 2009), pp. 18-24. 


\title{
PALERMO IN THE 14TH-15TH CENTURY: THE URBAN SOCIETY
}

\author{
E. Igor Mineo
}

\section{Introduction. The Formation of a New Community at the END OF THE 13TH CENTURY}

The chronological limits of this essay cannot be fixed with absolute precision, since they are determined by the type of perspective we choose to adopt regarding the "social" world of a great city. Our point of departure is, however, traditional. Despite the new lines of enquiry developed over the last twenty-five years, the Vespers, which by tradition serve to cut Sicilian history in two (before and after 1282), help us to impose order upon the phenomena with which we are concerned. Our destination is far less easy to pin down, and we therefore need to identify more than one: 1392, and the restoration of royal rule, and 1516, which saw the death of Ferdinand the Catholic (and the definitive, though very troubled, passage to a new, wholly "Spanish" epoch), are dates of crucial importance for the entire island; as was $145^{\circ}$ for the capital, on account of a revolt that reveals much about the social geography of the city midway through the $15^{\text {th }}$ century.

The social processes that interest us here were not of course determined by the Vespers as such, indeed some important preconditions had been established earlier. In the latter half of the 13th century two discontinuities in the institutional context had occurred. We cannot tell exactly when, although it was probably after the middle of the century, the text of the customs was drafted, as a system of rules in some way produced by the community; ${ }^{1}$ later, in the Angevin period, a tendency arose, which after 1282 would become irreversible, to elect the city's officials and not to have them be appointed by the royal court. ${ }^{2}$ We are concerned here with

1 The texts were edited, with a commentary, by Vito La Mantia, Antiche consuetudini delle città di Sicilia (Palermo, 190o); see Ennio Igor Mineo, "Norme cittadine, sviluppo istituzionale, dinamica sociale: sulla scritturazione consuetudinaria in Sicilia tra XIII e XIV secolo," in Gabriella Rossetti, ed., Legislazione e prassi istituzionale nell'Europa medievale. Tradizioni normative, ordinamenti, circolazione mercantile (secoli XI-XV) (Naples, 2001), pp. 341-61.

2 Fabrizio Titone, Governments of the "Universitates": urban communities of Sicily in the fourteenth and fifteenth centuries (Turnhout, 2009), pp. 18-24. 
two very strong signals indicating the presence of a new form of community, contrasting with that of the cities in the Norman and Swabian periods. These discontinuities emerged gradually in the second half of the 13th century; and yet they seem to be borne out by a documentary "mutation" occurring in Palermo as late as the beginning of the 14th century, and involving the sudden appearance of acts produced by local officials (and of a rudimentary "archive" of the city as well).

The importance of the Vespers for my argument therefore lies in its major consequence, namely, in the formation, together with a new and smaller Kingdom, of a different institutional structure, in which the urban "peripheries" (amongst them many densely populated centres), took on a more prominent, and more independent function than in the past. This change concerned the demesne, that is to say, the space common to the Crown and to almost all the cities, and found expression precisely in the self-government of these latter. In this context Palermo's location within the royal demesne is beyond dispute: in the sources, emphasis is often laid upon the specificity of the Palermitan urban space as demesnial space, distinct from feudal and ecclesiastical space alike. This institutional specificity was mirrored first and foremost in the rules for the election of officials, in which process protagonists from the feudal aristocracy could play no part. ${ }^{3}$

This essay is therefore concerned with the impact of the growing institutional autonomy of a great city upon the characteristic features of the wider society or, if you will, with the attribution of a clearer community status to one of the most heavily populated urban centres of the peninsula (between 40,000 and 50,000 inhabitants in 1277). One symptom of this transformation is evident in the change in the city's form by contrast with the Norman-Swabian period. The macroscopic differences were twofold. Firstly, in place of a multi-ethnic, linguistically plural city we now find a centre homogenized under the sign of "Latinity." Indeed, the spatial arrangement of the Norman city had served to distinguish between the inhabitants in terms of a complex series of criteria, first of all linguistic and religious, but the process of Christianization and Latinization (which, at the end of the 12th century, was already under way) had not yet defined clearly distinct spheres. At the end of the 13th century (so far as we

3 See Adelaide Baviera Albanese, "Studio introduttivo," in Lia Citarda, ed., ACFUP 3 (Palermo, 1984), pp. XX-XXIX, Ennio Igor Mineo, "Città e società urbana nell'età di Federico III: le élites e la sperimentazione istituzionale," in Federico III d'Aragona re di Sicilia (1296-1337) (Palermo, 1997), pp. 128-31. 
know), this pluralism had not disappeared but it had become somewhat attenuated, or its meaning had altered: a significant Jewish presence was indeed still in evidence, but the Muslims had all but disappeared, and the Greeks had been in large measure absorbed. As a consequence of these developments, such cultural pluralism as remained was within the Latin and Catholic sphere, and was fed by migratory flows from many different Italian areas (especially from the central and northern cities) and, more broadly, from Europe (especially from the Iberian peninsula). The second macroscopic difference concerns the fact that, in place of a composite city, consisting of two fortified centres, the Cassaro and the Khālișa/Kalsa, plus three suburbs outside the walls, ${ }^{4}$ there was now a unified city divided into five "quarters," of which only one, the Cassaro, could be traced back, spatially and in name, to the Islamic and Norman past. The other four quarters, the Seralcadi, the Albergheria, Porta Patitelli and the Kalsa, were administratively engendered areas which only in part corresponded to the pre-existing territorial units (from the Islamic and Norman-Swabian periods); indeed, their boundaries had been demarcated at a late date (probably in the Angevin period, when the term "quarter" itself made its first appearance). ${ }^{5}$ The city would retain this same physiognomy up until its reinvention at the end of the 16 th century.

\section{The Aristocratic Map in the First Half of the 14Th Century}

This space was inhabited by a large population whose characteristics were apparently not very formalized. Indeed, historians have been struck by the relative "informality" of Palermo's social structure, if compared with that of other great European cities. I have in mind here the almost total absence of tangible reflections of collective representations deriving from the community's history, the sheer difficulty of recognizing precisely who the different social actors were, and the general character of the urban microcosm, which, by comparison with other cities at this same date, was relatively lacking in corporate structures.

4 This would seem to be how things were at the time of Ibn Hawqal's description in the 1oth century, see Adalgisa De Simone, "Palermo araba," in Storia di Palermo, II (Palermo, 2000), pp. 90-98.

5 On these aspects of the city's reorganization, see Elena Pezzini, "Articolazioni territoriali a Palermo tra XII e XIV secolo," MEFRM 116/2 (2004), 729-801, and in particular pp. $734-38,787-90$. 
The relatively undefined nature of the social actors could, generally speaking, be connected to the fact that between the 13th and the 14th centuries the process of constructing a new political arena in the city, one based upon the principle of autonomy, had only just begun. The difficulty of putting a face to such actors is mitigated the higher up the social scale we go, but even the sphere of political pre-eminence has blurred outlines, precisely because the rules and roles of the new order still seem, in retrospect at any rate, to be in the making.

In short, there were criteria of individual distinction, or modes by which the prestige of some categories were recognised, but Palermo lacked a privileged space endowed with sufficiently formalized characteristics. The city as such did not produce enduring distinctions between defined groups, and, conversely, it was traversed by "external" signs: in particular those deriving from the hierarchical order of the Kingdom, inherited from the Norman-Swabian past, which no matter how precarious or on the way to being rewritten, was nonetheless clear-cut, and showed scant regard for the urban stage.

The above interpretation is borne out by certain sumptuary norms promulgated by Frederick III between the 1310 and the $1320 s,{ }^{6}$ and again by a number of later royal interventions, which were more circumscribed and based this time on urban petitions. Frederick III's norms were intended to apply to the whole Kingdom but, as we shall shortly see, they were of particular relevance to Palermo. We can subdivide them into two groups, on the one hand statutes 86 to 104, on the other statutes 105 to 107. It is best to begin with these latter, which were explicitly addressed to "counts, magnates, barons, knights and all those who receive prebends from the court"7 and which contain detailed regulations regarding the dress and consumption of the feudal lords and their retinues. We are therefore concerned here with the disciplining of the feudal aristocracy, a milieu that was fairly well defined, endowed with its own juridical status inherited from the Norman-Swabian period and, in particular, from the legislation of Frederick II. In this case sumptuary norms do not suppress distinctions, indeed, they presuppose them, while at the same time conferring a code upon them and imposing restrictions.

\footnotetext{
6 Francesco Testa, Capitula Regni Siciliae, I, Palermo 1741, pp. 88-98.

7 "Comites, magnates, barones, milites habentes a curia certam provisionem" (or in another, more explicit phrasing, "terram, provisionem, aut stipendia").
} 
The first group of norms is based upon a different logic, typical of urban milieux, entailing the suppression of luxury, and especially in women. Since such a logic does not make provision for exemptions (given that the "aristocracy" is disciplined separately), when some exemptions do nonetheless emerge they indicate distinguishing criteria relating to the social body that have nothing to do with the traditional aristocratic lexicon and that only the cities are capable of generating. In other words, it is obvious that this group of norms had been conceived by the urban communities, which could well have negotiated them also. Upon closer scrutiny we find that the above regulations may be divided into three distinct clusters: one relating to male clothing (statutes 86-89), one relating to female adornment (statutes 90-97) and one relating to ceremonies (weddings, the dubbing of knights, funerals: statutes 98-104). Let us focus, for brevity's sake, on the statute of most interest to us, the first. Statute 87 forbids anyone to wear "gilded spurs, and gilded reins, saddle and stirrups, unless he be a knight decorated with the chivalric cingulum"; however, "doctores cuiuscumque professionis, iurisperiti et medici, praedicta, sicut milites, portare possint." These same categories are then said (in statute 88) to be at liberty to don the vair; magni burgenses and mercatores, however, may only wear it on the head.

We thus learn that some exemptions from the ban upon ostentatious displays of luxury in the city were provided for, and that they do not concern the seigneurial aristocracy. Various categories of person were interested in the considerable symbolic possibilities offered by decoration of horses and horsemen and in particular by special items of clothing such as the vair: the dubbed knights, of course, but also the doctores cuiuscumque professionis, the jurists, the doctors, the magni burgenses et mercatores. Moreover, some interesting information emerges with regard to the category that would seem to be the most prestigious, that of the milites.

This same source represents the milites as an ambiguous category: in accordance with the Swabian juridical tradition they constituted the lower segment of the feudal hierarchy (belonging to the sphere of "comites, magnates, barones, milites," as we have seen) and were treated in the cluster of statutes relating to this latter, as privileged subjects. But they also belonged to the urban world, and here the attributes of the miles lost, in part, their exclusivity. In short, according to one group of norms (105-107), the milites display marks ostensibly placing them within the feudal hierarchy, while according to the other (86-104) they share with other subjects, extraneous to the sphere of feudality, a further set of distinguishing marks, such as the vair and the ornaments displayed when on horseback, but also 
the restrictions imposed upon ostentation. For example, statute 86 forbids everyone to wear ornaments made of pearls, gold and silk.

It is thus apparent that there existed some privileged social categories peculiar to the urban milieu: this aristocracy seems, however, to have lacked clear-cut internal demarcations and to have included economically prominent groups (magni burgenses, mercatores), professionally qualified subjects, lawyers, notaries, bureaucrats. The hierarchical framework that emerges is elusive, and the milites formed part of it not as a separate segment but as a prestigious condition which eminent individuals could attain to, but which was not an obligatory goal. ${ }^{8}$ Chivalric rites were open ceremonies. Indeed, statute 89 addresses "those who aspire to, and desire chivalric honour, whatever their estate or age may be": these subjects may not don the vair, not even on their heads, they may not wear red footwear and they may not (as already laid down in statute 87 ) have, when riding, reins, stirrups and spurs decorated with gold (whereas someone not aspiring to the militia may wear the vair on their head).

The assumption of the cingulum would seem therefore to have offered an opportunity for social advancement. Indeed, a fair number of prosopographic profiles confirm that it was not unusual to see merchants, notaries and urban officials acquiring the militia. ${ }^{9}$ But this advancement, which led neither to the forging of coherent identities, nor to the birth of "chivalric" dynasties, was always ambiguous.

In practice, the privileged status of the milites entailed only a small number of concrete advantages, in part fixed by law: the right, obviously, to bear arms, exemption from some taxes, such as the rare collette (that is the direct taxation), ${ }^{10}$ and the exclusive entrusting to them, according to custom, of some prestigious offices, such as that of Praetor of Palermo. Yet the milites did not even monopolise the offices which were markedly military in content, ${ }^{11}$ nor can we be certain that they were excluded from indirect taxation;12 furthermore neither they nor the fief-holders had a

8 Ennio Igor Mineo, Nobiltà di stato. Famiglie e identità aristocratiche nel tardo medioevo. La Sicilia (Rome, 2001), pp. 179-84.

9 Ibid.

10 Statute 56 of Frederick III, Testa, Capitula, p. 75 .

11 In 1328 the captain and justiciar of Palermo was the judge Roberto de Laurencio, ACFUP 5, ed. Pietro Corrao (Palermo, 1986), p. 36.

12 The taxation of the milites is taken for granted in a document from 1328: the officers of Palermo ask those of Corleone to respect the privilege of the citizens of Palermo and to exempt the nobilis dominus Giovanni de Cosmerio, miles, from being taxed on property owned within the territory of Corleone (ACFUP 5 , pp. $\left.3^{8-40}\right)$; but the privilege concerns Giovanni as civis and not as miles. 
privileged tribunal of their own. ${ }^{13}$ The ambiguous status of the milites therefore derives from the convergence, within one and the same notion, of a role-increasingly residual-deriving from the past, and of a current practice which rendered the militia an urban phenomenon, that is to say, a status to be acquired in the city, individual rather than dynastic, and compatible with other forms of influence. ${ }^{14}$

The other figures who occupied the upper echelons of Palermitan society, and who were permitted to use the relevant titles, came from the world of administration and of the legal professions. In Palermo, as in the other Sicilian cities, the holding of urban offices represented a sure path to social advancement: gradually, however, as the framework of the magistracies grew more complex, some proved to be more influential than others. What strikes us in fact, prior to the emergence of the role of jurats, is the uncontested prominence of the judges. They constituted the central organ of the communitas, the Praetorian court, and a distinction was in fact made between "iuristi" (that is to say, those with jurisprudential expertise) and ydeoti (lacking in this same professional status). ${ }^{15}$ The judges, one and all, maintained their right, once they had issued a mandate, to be adorned with that title. ${ }^{16}$ When, however, in 1332 , they were, like the milites, exempted from the collette, the privilege was understood to be for life for the iuristi judges, but only for the period in office for the ydeoti judges. ${ }^{17}$

The sources make it plain that in any case the possession of juridical wisdom and expertise, even aside from the question of office-holding, brought prestige, distinction even. Indeed, all these categories-and the notaries must be numbered amongst them-were to be found, along with the milites, at the heart of the ceremonial sphere. In documents from the age of Frederick III references are sometimes made to the luminaria held on 15 August to celebrate the Assumption. On that occasion some categories of citizen would light their own candle: a document from 1329 refers explicitly to the milites, to the iudices et licterati, to the notarii et scriptores

13 It is easy to find cases of milites and fief-holders being judged by the ordinary tribunal, the praetorian court. For some examples, see ACFUP 5, pp. 9-17, 35-37, 61-69, 180-182; ACFUP 8, ed. Cecilia Bilello and Anna Massa (Palermo, 1993), p. 143.

14 See D'Alessandro, Terra, pp. 128-47.

15 Beatrice Pasciuta, "In regia curia civiliter convenire," Giustizia e città nella Sicilia tardomedievale (Turin, 2003), pp. 134-47.

16 See D'Alessandro, Terra, pp. 134.

17 Michele De Vio, Felicis et fidelissimae urbis panormitanae selecta aliquot privilegia (henceforth Privilegia), (Palermo, 1706), p. 130; and see Pasciuta, In regia curia, p. 135. 
curie. ${ }^{18}$ On closer inspection we find that it is the public sphere of the universitas that is represented in this triple order: that of the milites, whose candles weighed twice as much as that of the judges, was indeed the most prestigious, but always within a context that sees it referred to the other social and professional milieux.

By way of conclusion, the public stage does indeed appear, in the first decades of the 14th century, to have been characterized by a marked degree of social informality. However, we can discern signs, in the "local" institutional sphere then under construction, of a process whereby in part new distinctions and roles were being produced. In saying that these roles were specifically urban and that they appeared to be neither strictly defined nor juridicized, my intention is to stress that they were individual roles which could be acquired, not dynastic ones ascribed to some private identity (which the sources do not draw attention to, and the institutional logic then taking shape does not allow for). Such roles were superimposed upon the traditional roles of the supralocal feudal and institutional world, whose meanings were thus in part changing. We cannot see this historical process close up: but the "internal" form of the city analysed here continued to cohabit with the "external" powers. Indeed, great weight was attached, and ever more visibly in the mid-14th century, to subordination to the powerful seigneurial families, and especially to the family that dominated urban space, the Chiaromonte, whose "nobility" appeared incommensurable with the prestige of the urban aristocracies, to which, however, many milites belonged.

\section{GUILDS}

The document from 1329 does not directly describe the mid-August ceremony. Another document, however, which is much later (from 1385), contains a detailed list of the participants, and poses a problem that we cannot solve, given the fact that it makes almost no mention of the social categories which had featured in the earlier document. Yet the text from 1385 is important, because it describes the bearers of $5^{8}$ candles lit for the Feast of the Assumption: ${ }^{19}$ alongside those from, the royal court (even

18 ACFUP 5, doc. 70, p. 128.

19 Vincenzo Di Giovanni, La topografia antica di Palermo dal secolo X al secolo XV, I (Palermo, 1889), pp. 84-86. Cf. Salvatore Leone, "Lineamenti di una storia delle corporazioni in Sicilia nei secoli XIV-XVII”, Archivio Storico Siciliano 2 (1956), p. 89, n. 33. 
when, bizarrely enough, the throne was empty) and the Archbishop, appear the candles of 44 professional categories and of the 5 quarters of the city. We do not know if this source is wholly reliable; nevertheless it does clarify the ceremonial function of the crafts and the quarters, which had never been so explicit before, and thereby helps us to orientate ourselves on the complex terrain of guild networks, and to understand the relationships of solidarity between members of the craft associations.

This time my starting-point is the customs of the city, which contain just one article dedicated explicitly to the crafts, number $77 .{ }^{20}$ It is hard to date this article precisely, and all we can say for sure is that it is earlier than the end of the 14th century, given that it contains no reference to the guilds, which were active, as we shall see, at least from the 1410 .

The article states that the "artifices omnes mechanicarum artium," whether cives or exteri, can practice "eorum artificium" and work "libere absque alique servitude proinde Curie facienda." Mention is then made of barbers, bankers, and of venditores rerum, invariably confirming their freedom to practice. To this list are added the pauperes mulieres who may make bread without being obliged to pay taxes, "quantumque turpem ac sordidam vitam ducant." Finally the blacksmiths are mentioned.

The picture that emerges from this source, and from various others, is fairly coherent. In the first place, between the 13th and 14th centuries the counterposing of vile and honoured activities did not have practical and institutional consequences (as it would once we are well into the $15^{\text {th }}$ century). Secondly, we can clearly discern the full freedom of initiative available to individuals, be they cives or exteri, which was elsewhere a privilege of prestigious professional categories. ${ }^{21}$ Indeed, the next article in the customs, number 78 , confirms that there was a free trade regime which was incompatible with the presence of guilds vested with monopolistic privileges: "Let all the citizens of Palermo be allowed to weigh, sell and acquire cheese, meats, wool, hemp, cotton and any other commodity purchased wholesale ... and not be required to pay anything to the Court." ${ }^{22}$ These words sanctioned complete freedom of trade, even in a strategic sector such as textile production. To quote a well-known example, when in 1322 the Genoese Alafrankino Gallo sought to embark upon the production of cloths he had to reckon not with the local guild organizations (there were

\footnotetext{
20 La Mantia, Antiche consuetudini, pp. 214-15.

21 In article 68, for example, doctors' complete liberty to practice is attested (ibid., p. 204).

22 Ibid., p. 215; see also art. 75 on selling meat retail, ibid., pp. $210 f f$.
} 
none) but with the Universitas and with the king. The latter, by way of confirmation of what had been decided by the city's officials, decreed that: "Alafrankino, together with heirs and partners in perpetuity and other foreign workers, and the sons of these latter, practising the same crafts alongside him, [should] be free and exempt from any "angaria..., from royal and personal contributions, from all tolls, from collette, and from any other burdens." 23 It is evident that in the 14th century the regulation of professional and artisanal activities was at the bidding of officers elected on a territorial basis, and the king's intervention simply ratified the stance adopted within the Universitas. Thus, when the king, in 1330, endorsed a group of statutes referring to the office of catapan, ${ }^{24}$ which some categories of artisan and merchant were supposed to abide by, there was not a single mention of guild associations. By the same token, article 61 of these same customs subordinated the activities of the artifices to the supervision of the catapans (or maestri di piazza).$^{25}$

We cannot speak, in sum, of guilds of Palermo in the sense that such a term assumes in many mercantile cities in the Europe of this period, namely, organisational and jurisdictional independence, or the exercising of a monopoly over a specific activity. Admittedly, there is something reminiscent of acts of self-regulation in the reference, again in article 77 , to a statute of barbers, smiths and blacksmiths. Yet only rarely do we come across any public trace of situations in which those plying the same trade coordinated their activities or displayed solidarity, since such situations pertain to a "private" sphere, consisting of the culture of work and of forms of territorial settlement which do not leave a lasting mark on the documentation. ${ }^{26}$

Other details, for example those relating to young mens' apprenticeship contracts, which never mention craft statutes, ${ }^{27}$ serve to confirm this

23 De Vio, Privilegia, pp. $82 \mathrm{ff}$.

24 Ibid., pp. 114-24.

25 La Mantia, Antiche consuetudini, p. 199.

${ }^{26}$ For example, we know something about the intense relationships between saddlers, see Elena Pezzini, Halcia: un quartiere della città di Palermo nel primo Trecento, Doctoral thesis in medieval history, Università degli studi di Palermo, IX ciclo (Palermo, 200o), pp. 293-98. The fact that in 132217 saddlers were exempted all at the same time from service in the night watch [ACFUP 6, ed. Laura Sciascia (Palermo, 1988), pp. 16-17] obviously had nothing at all to do with even an embryonic corporate structure (given that the exemptions were granted to individuals, and not to some association of theirs).

27 Cf. Pietro Corrao, "L'apprendista nella bottega artigiana palermitana (secc. XIVXVII)," in I mestieri. Atti del II Congresso internazionale di studi antropologici siciliani (26-29 marzo 1980) (Palermo, 1980), pp. 137-44. 
judgement. By the same token, scholars have doubted the actual existence of monopolies over activities linked to trade and money-changing. ${ }^{28}$

It is not until the ordo cereorum of 1385 that we find any evidence for clearly distinct and publicly identifiable forms of corporate organization. As we have seen, in the list of $5^{8}$ titulars of candles borne in procession, on 15 August, 44 of them represent particular artisanal and professional activities. Being isolated and differing from the earlier notices of the luminaria of the Assumption, such as that of 1329 (which makes no mention of artisans' candles), ${ }^{29}$ the evidence from 1385 is hard to evaluate. The only plausible interpretation would be one that sets it within an open process of construction of corporate mechanisms. Yet it must have been a drawnout process, whose nature we can only guess at. The Crafts listed in the ordo may have taken part in the ritual, but there is no evidence of their being granted any role in the political sphere.

Furthermore, the supposition that in the mid-14th century the formation of more formalized associative structures was an entirely open process is confirmed by the first explicit notices of the presence of lay confraternities, which appeared sporadically in the 1340 and then with slowly increasing frequency. ${ }^{30}$

It is therefore no coincidence if it was only at the end of the century that the presence of the confraternities appears to be regular, and that, in this same period, at the time of the Martinian restoration, the first signs appear not so much of the self-disciplining of the craft workers (which may perhaps have occurred earlier) as their complete incorporation into the public life of the city. In 1399 the city asked the king if the sugarmakers' consuls might be elected; later, in the 1410s, we come across other notices regarding artisan consulates, ${ }^{31}$ and subsequently actual statutes such as those of the silversmiths, approved in 1447, whose importance lies in the fact that they confirm, a posteriori, the continuity of the ceremonial space attested by the ordo of $1385 .{ }^{32}$ From then on the process

28 Stephan R. Epstein, An Island for itself. Economic development and social transformation in late medieval Sicily, Past and Present Publications Series (Cambridge, 1992), pp. 197-199, 358-6o.

29 ACFUP 5, p. 128. There is a note referring to the milites' candle in 1335 also, see ACFUP 6, p. 116 .

30 See a list of statements in Vita Russo, Il fenomeno confraternale a Palermo (secc. XIVXV) (Palermo, 2010), pp. 239-286.

31 Henri Bresc, Un monde méditerranéen. Economie et societé en Sicile 1300-1450 (RomePalermo, 1986), I, p. 212 (table no. 29).

32 Fabrizio Titone, "Il tumulto popularis del 1450. Conflitto politico e società urbana a Palermo," Archivio storico italiano 163 (2005), 56-58. 
of institutionalization of a "general" guild system, representing the whole of the artisanal universe, advanced in fits and starts, being completed, probably, only after 1460.33

This does not mean that the artisans won full political competence. For example, they remained generally outside the local offices, although on one occasion, in 1448, the Universitas, or a part of it, regretted that the catapans' role (increasingly entrusted to "homini comuni et ignoranti", namely, workers and artisans) had gone into decline, ${ }^{34}$ and on another, in 1472, within an important corpus of statutes, it stipulated the exclusion of the guilds and of the artisans from the office of ydeota judge and, once again, from that of catapan. ${ }^{35}$ Yet we certainly observe their presence at meetings of the city councils, at any rate from the $1440 .^{36}$ Indeed, the magistri were protagonists, together with the highly variegated populus, in the various phases of the $145^{\circ}$ revolt.

Now, it was not by chance that in 1451, immediately after the ending of the revolt, Alfonso approved a statute whereby the representatives of the Universitas asked that consuls no longer be elected by the artisans. The latter, the petitioners objected, caused tension and conflict whenever they took on posts in government, because they were persuni idioti et illecterati who often clashed with "His Majesty's ordinary officials and those previously mentioned." 37

Of course the consuls did in fact go on being elected, ${ }^{38}$ even if the episode of rioting was bound to disrupt the relationship between the nascent guilds and the city institutions. However, documents like this enable us to grasp that by now, generally speaking, the corporatization of labour was well advanced, and that it was not uncommon for local politics, by contrast with half a century earlier, to be more or less intensely affected by it; but also that it generated tensions which could be very acute, and in some cases, including that of Palermo, well documented.

33 Ferdinando Lionti, Delle antiche maestranze palermitane, Palermo 1883; Gabriella Lombardo, "Tra politica ed economia: le corporazioni di mestiere nella Sicilia moderna", in Marco Meriggi and Alessandro Pastore, eds., Le regole dei mestieri e delle professioni. Secoli $X V$, XIX (Milan, 200o), pp. 326-45.

34 De Vio, Privilegia, pp. 309 and cf. Titone, "Il tumulto," pp. 63ff.

35 De Vio, Privilegia, pp. $388 \mathrm{ff}$.

36 Titone, "Il tumulto," p. 58, nota 40.

37 Testa, Capitula, I. p. 367.

38 For example, the consul "de li drapperi de li panni" in 1457, ibid., p. 417. 


\section{Merchants, Foreigners, Citizenship}

There were no significant exceptions to this weakly corporate morphology: even the strongest professions still lacked a highly formalized and structured organization. We have seen, for instance, how the merchants appear not to have enjoyed a separate jurisdiction. Indeed, in $1338,{ }^{39}$ and then again a century later, in 1442 , the Universitas was driven to ask the royal court to authorize a merchant tribunal presided over by the praetor "advised by two merchants... who shall be called consuls," and if the parties should wish to appeal, "another two or three merchants" elected by jurats might intervene..$^{40}$

The status of the merchants constitutes another crucial feature in the picture we are trying to compose here, not only on account of the influence commercial brokers brought to bear upon the social fabric of a great Mediterranean city, but also because reflecting upon their presence raises the more general theme of foreigners; indeed, from the foundation of the Norman kingdom many of the merchants active in Palermo, as in other cities in the South of Italy, in fact came from distant cities, both Italian and beyond the Alps.

What particularly concerns us is the relationship between this type of immigration and urban society, and what precisely such a relationship reveals to us about this latter. About the merchants whom the sources describe as exteri or foresterii we are especially interested in the meaning of their displacement overseas and of their dynamics of settlement (and not in that of their circulation around the routes of international trade). Their mobility had multiple causes, and the "macropolitical" ones (for example, Sicily's transfer after the Vespers into the Ghibelline-Aragonese camp), though important, ought not to be overestimated. The same applies to "macroeconomic" factors. In other words, we cannot suppose that brokers' choices formed part, in the ordinary course of things, of a coherent plan of functional relationships between economic regions or between actual states. More realistically the merchants' presence in the South facilitated its integration into supra-regional markets, and made possible a more effective exploitation of the resources a kingdom such as the Sicilian could lay aside, that is agricultural products for which the

39 De Vio, Privilegia, p. 216.

40 Savagnone, "Capitoli inediti della città di Palermo", Archivio storico siciliano n.s., 26 (1901), pp. 107-108. The king, Alfonso the Magnanimous, would in part approve subordinating the actions of merchants to the authority of the judge of the first appeals. 
demand (except perhaps in the latter half of the 14th century) regularly exceeded the supply..$^{41}$ Moreover, that presence was also a response to a comprehensive call for technical competences and skilled labour voiced by southern society, in the sector of exchanges and of an already financialized economy, likewise in the sector of bureaucratic or financial and book-keeping competences, ${ }^{42}$ and, lastly, in that of artisanal and manufacturing activities. In short, one of our points of departure in analysing this presence is the fact that the Sicilian economy, early integrated into the Mediterranean market, was not harmed by the activity of foreign brokers. The other is the sheer complexity of the social spectrum of immigration.

I would moreover stress that the causes for the merchants' displacement are better understood through specific individual strategies (both of individuals and of collective subjects such as families, commercial partnerships etc.) rather than in terms of the "penetration" achieved by an undifferentiated community, Genoese or Pisan, which might be thought to represent the rational interests of the mother country. On the contrary, it was the Sicilian state, that is the Crown, that might have an interest in availing itself of the financial acumen, the technical abilities and the name of many brokers active at an international level. By the same token, it was the state which, in its relationships with technicians and financiers prepared to be mobile, could filter and give a direction to foreign settlements, encouraging or discouraging them as the case might be, and not always applying the logic of a grand international policy. ${ }^{43}$

Granted these premises, and reverting again to Palermo, it is readily apparent how, especially at the beginning of the period that concerns us here, the presence in considerable numbers of foreign merchants would seem to tally with the weak institutional structuring of the Sicilian cities and the fragile identity of its ruling groups, characteristics which made of them more open and cosmopolitan places. We have already seen how the customs guaranteed complete liberty of economic initiative to the exteri also. This freedom of movement found expression in the monopolising of some sectors of the local market, but not in the propensity to maintain (or to construct) an identity that was separate from the local urban

41 Epstein, An Island to Itself, pp. 284-286.

42 Mario Del Treppo, "Stranieri nel regno di Napoli. Le élites finanziarie e la strutturazione dello spazio economico e politico," in Gabriella Rossetti, ed., Dentro la città Stranieri e realtà urbane nell'Europa dei secoli XII-XVI (Naples, 1989), pp. 181-184.

43 Ibid., p. 197, Giuseppe Petralia, "I toscani nel Mezzogiorno medievale. Genesi ed evoluzione trecentesca di una relazione di lungo periodo", in Sergio Gensini, ed., $L a$ Toscana nel secolo XIV. Caratteri di una civiltà regionale (Pacini, 1988), pp. 287-336. 
context, that is to say, the identity of those belonging to a foreign nation. We should then linger over one of the fundamental aspects of this freedom, that is, the minimal difficulty, for a large part of the period we are concerned with, of acceding to citizenship, all the more significant when, as was the case here, the theatre of operations was a great city. In mercantile centres, such as Palermo, Trapani and Messina, the high degree of receptivity was thus matched by a far from rigid model of citizenship. Indeed, this model rendered it a simple matter to obtain citizenship, and, in principle, did not exclude multi-citizenship. ${ }^{44}$ On several occasions, in the course of the 14th century, the city negotiated with the king over how to discipline citizenship: first of all in 1305, Frederick III confirmed certain privileges granted the city by his predecessors, and extended to Palermo concessions formerly granted to Messina; ${ }^{45}$ then, in 1335 Peter II, and in 1346 Louis ratified these dispensations, clarifying some controversial aspects relating precisely to the relative ease of obtaining the civilitas. ${ }^{46}$

In describing with great precision which subjects enjoyed immunitates and libertates, the privilege of 1305 thus tells us just what it meant in Palermo to be a civis. The condition of civis referred to those who were natives of the city (oriundi) and lived there; to those who came from outside (exteri) and married a woman who was oriunda, or to those who moved to the city with wives who were not oriunde with animo habitandi et morandi and who remained for the space of one year, one month, one week and one day; to widows who were exteri but who continued to dwell in the city, provided that they did not remarry elsewhere. The attribute of civis was thus somewhat changeable, easily acquired but as easily lost. Those cives, even if oriundi (as specified), who did not have any family and intended to live elsewhere, forfeited their enjoyment of the immunitates and libertates inherent in citizenship.

The statutes approved by Peter II in 1335 confirmed the above dispensation, and furnished some additional particulars. First of all, they confirmed that it was the universitas that granted civilitas, ${ }^{47}$ and that what

44 Even if of course the picture is very variable and changes with the passage of time: Del Treppo, "Stranieri", pp. 225-27, Andrea Romano, "La condizione giuridica di stranieri e mercanti in Sicilia nei secoli XIV-XV," in Mario Del Treppo, ed., Sistema di rapporti ed élites economiche in Europa (secoli XII-XVII) (Naples, 1984), pp. 113-32, in particular, pp. 128-31.

45 De Vio, Privilegia, pp. $37 \mathrm{ff}$.

46 Ibid., pp. 140, 176-78.

47 Which does not rule out the possibility of the crown having granted citizenship as a privilege, see Henri Bresc, "L'étranger privilégié dans les politiques municipales: Palerme (1311-1410) et Draguignan (1370-1440)," in Claudia Moatti and Wolfgang Kaiser, eds., Gens 
was involved was not the conferring of an irrevocable quality. This is evident, for example, in the case of the exteri considered "ut panhormitani cives," who in time of war had abandoned their houses and returned to the places whence they came, and who therefore had not only renounced privileges but also had shirked "velut ingrati" the burdens that membership of the community imposed upon them: their citizenship should be revoked, along with their prerogatives and they, once again, "velut exteri haberi debeant et tractari." 48 Suppose we compare the norm with one of the many routine certifications issued on 6 March 1312 to one Orlando Biricterio. Orlando was an oriundus; "for some time now he has been and is a Palermitan citizen, having in this same city, a wife, moveable and immoveable property, and his own residence, he has participated in the burdens and obligations of the city ut civis cum civibus urbis ipsius." ${ }^{49} \mathrm{We}$ thus grasp the key point: the condition of being welcomed as a foreigner is, together with an uninterrupted stay and family ties, an effective commitment to sustaining the burdens of the community (in primis paying the relevant taxes), and therefore not being an encumbrance. In Sicily, as elsewhere, this latter was a recurrent criterion invoked in order to recognise who was an integral part of a community. In Palermo too the city belonged to those who lived there, and citizenship was above all a relationship; the notion of oriundus was itself relative, serving to pin down the meaningful relationship between recent immigrants and long-term inhabitants. Therefore, just as the city was not a community rooted in the past-memory of which, not by chance, was not preserved-so too citizenship was not a sign of membership in that imaginary community, in the community of the ancestors.

It is thus obvious that this open model of citizenship fostered mobility and the taking root of those not born in Palermo, and that, conversely, it posed no obstacle to those who came to do business or to lend their services while maintaining links with their place of origin. This is why, in analysing local society, it is preferable to concentrate more on individual trajectories, on the concrete articulation of kinship networks and of contacts, either for business or not, between individuals and nuclei of brokers, than on the putative (and hard to document) strategies adopted

de passage en Méditerranée de l'Antiquité à l'époque moderne. Procédure de contrôle et d'identification (Paris, 2007), p. 215.

48 De Vio, Privilegia, p. 141.

49 ACFUP 1, eds. Fedele Pollaci Nuccio and Domenico Gnoffo (Palermo, 1892 ; anastatic reprint 1982), p. 56. 
by specific communities. The study of individual trajectories suggests that foreign merchants frequently opted for prolonged immersion in the host city, invested in immoveable property and land, sometimes marrying or even dying there, and yet they nonetheless might still maintain close or intense links with those who had undergone similar experiences. It may therefore be no accident that so few traces of the community life of the nations remain. We know of lodges and consulates, but nothing, or virtually nothing, about their functioning as institutions. ${ }^{50}$

A case that has been much studied, that of the Tuscans, confirms the above analysis. There had long been a Tuscan presence in the South, and the Ligurians, too, had long been on the move; ${ }^{51}$ in either case we have good cause to go as far back as the Norman period. The Tuscans, however, began to arrive in far larger numbers, readily perceptible from the end of the 13th century. What is striking here is the limited solidarity evinced by those who moved to Sicily, and their readiness first to extend their stay and then to settle, and to take on a role in local public space. Between the last decades of the 13th century and the first half of the 14th century there thus emerged, alongside the great merchants linked more or less directly to the crown, a host of middling and small actors who only in some cases acted on behalf of companies operating on the international market. Such actors came not only from the great cities, such as Pisa, Florence, Lucca or Siena, but also from many minor centres, and often we encounter them not only in Palermo, and in other major trading centres such as Messina and Trapani, but also in communities inland, and involved in traffic of a local nature.

In these latter circumstances it is hard to recover the origin of the individuals and the defining features of an important community interaction that went beyond solidarity between relatives and correspondents. In this emigration those who were rapidly assimilated exerted a great deal of influence, thereby reinforcing the "Latin" cultural tone of the ancient Islamic island and its capital. In order to comprehend such a long-term

50 Bresc, Un monde, I, pp. 380-9o (and Table 78).

51 On the Tuscans in Sicily see Giuseppe Petralia, Banchieri e famiglie mercantili nel Mediterraneo aragonese. L'emigrazione dei pisani in Sicilia nel Quattrocento (Pisa, 1989), Id., "Sui Toscani in Sicilia tra Due e Trecento: la penetrazione sociale e il radicamento nei ceti urbani," in Marco Tangheroni, ed., Commercio, finanza, ragione pubblica. Stranieri e realtà urbane in Sicilia e Sardegna nei secoli XII-XV (Naples, 1989), pp. 129-218; on the Genoese, and on the presence of other merchant communities in Sicily, see in general Pietro Corrao, "Mercanti stranieri e regno di Sicilia: sistema di protezioni e modalità di radicamento nella società cittadina," in Sistema di rapporti, pp. 87-112. 
phenomenon, the link between mobility and a shift in identity should be stressed. This link found expression in concrete opportunities for those who took up the challenge of travelling to Sicily, and for those who, in Tuscany, kept in touch with relatives and correspondents who were active in Sicily and whose return could not be taken for granted.

Integration into urban society, and likewise into the milieu of its ruling groups, therefore did not necessarily require extended stays. ${ }^{52}$ To give just one example, in 1335 the confirmation of citizenship issued to the providus vir Puccio Iacobi, a prominent merchant and on several occasions a city official, probably in Palermo since the immediate aftermath of the Vespers, defines him as "one of the most honoured and best citizens of the city, who, together, with his fellow citizens, took upon himself its honours and its burdens." 53

The dynamics of integration were very diverse. There was no clash between naturalisation and the tendency of Palermitans who were of Tuscan origin to cluster together. Indeed, the one inclination (the propensity to live in close proximity) probably facilitated the other. The majority of such Tuscans, and the Pisans in particular, thus lived in the quarter known as the Kalsa, and also in the one next to Porta Patitelli, where, alongside the other nations' lodges, the lodge of the Pisans was to be found. ${ }^{54}$ Nor is it an accident that the fulcrum of Tuscan commercial activity lay between San Francesco, the ruga Pisarum, Porta Polizzi and the port.

As for the Pisans, they were invariably a prominent part of the Tuscan emigration. Their community did, however, acquire particular characteristics from the early 15th century, after Florence's conquest of Pisa, in 1406, and the Mediterranean diaspora of a notable part of the city's ruling group. The lasting propensity of Pisans to head for Palermo and Sicily demonstrates, as we have seen, that it is not only a traumatic event (such as the end of political independence in the mother country) that will account for a tendency to emigrate and to switch citizenship. There is no doubting the fact, however, that it had become easier to settle permanently, and that it sometimes seemed to be obligatory, especially for the elites. Indeed, after 1406, this choice was chiefly made by a socially prominent segment and therefore more easily identifiable in identitary terms, being composed of subjects involved in banking and in large-scale trade. For this reason

\footnotetext{
52 Petralia, "Sui Toscani", pp. 215-218, Pezzini, Halcia, pp. $238 \mathrm{ff}$.

53 ACFUP 6, p. 112 (doc. 61). For the origin of Puccio and his offices, see Petralia, "Sui Toscani," pp. $142 \mathrm{ff}$. and note $42,215 \mathrm{ff}$.

54 Pezzini, Halcia, pp. 232-276.
} 
the ultimate outcome is all the more striking, since in so many cases it entailed complete incorporation into the ranks of the Sicilian-and, in particular, the Palermitan-aristocracy, an outcome that was reinforced in the latter half of the $15^{\text {th }}$ century. ${ }^{55}$

One may therefore readily understand just how difficult it is to discern the physiognomy of the community life of the mercantile "nations" in Sicily. The presence of the Pisans, for example, shows how the variable intensity of professional, familial and clientelistic relationships inside the world of those originally from Pisa was not matched by a clearly defined institutional organization, in the guise of a consulate and of jurisdictional autonomy, nor by the collective patronage of a place of worship. Indeed, the most heavily represented "nations," those of the Tuscan cities, did not have a consulate, whereas the Catalans did, even though the Catalan nation was not much given to settling in Palermo. ${ }^{56}$ As we have already observed, the main foreign settlements, in Palermo as in Messina, tended to exist as homogeneous urban segments, and to occupy continuous tracts of land, yet these solidarities did not lead to the construction of a distinct space with lodges and warehouses. Scholars have noted how in Palermo the boundaries between the different groups tended in practice to become blurred, and how, notwithstanding the (sporadic) presence of sacred spaces attributed to the various communities (churches, confraternities, chapels), S. Francesco became, by the 14th century, the church of the entire urban ruling class, "foreign" merchants included. ${ }^{57}$

\section{HiERARCHIZATION AND ARISTOCRATIZATION}

Let us now make a leap forward in time. Around 1450 Palermitan society had different characteristics to those we have brought to the fore so far. In that year a revolt erupted, the causes of which were as much economic as political, since grave scarcities in grain supplies converged with the demand for different, broader forms of political representation. ${ }^{58}$ The entire citizenry became involved in the revolt, and the sources relating to this episode reveal a mode of classifying the city's inhabitants which in the 14th century had not yet been mature. This mode involved a mechanism

\footnotetext{
55 Petralia, Banchieri, pp. 351-36o.

56 Corrao, "Mercanti stranieri," pp. 94, 107.

57 Bresc, Un monde, 1, p. 392; likewise Corrao, "Mercanti stranieri," p. 105.

58 Titone, "Il tumulto."
} 
of self-representation based upon the division of the social body into four distinct segments, namely, the gentlemen (gentilomini), the merchants (mercatores), the borgesi and the artisans (magistri). The meaning of these labels is in no way explicit. We are not concerned here with juridical distinctions or with an estate hierarchy, as could already happen in other European cities, but, generally speaking, with distinctions within the part of the population that was able to act in the arena of urban institutions. To put it briefly, gentilomini refers to the upper segment of the social scale, and comprises big landowners, big entrepreneurs (such as those involved in the nascent sugar industry): that is to say the highly diverse milieu of those who consistently acceded to the urban offices and who campaigned for the introduction of an oligarchical criterion governing the electoral mechanisms. The borgesi were above all small and middling landowners, in the main of properties termed burgensaticii, that is to say, estates juridically distinct from the feudal ones. Mercatores were probably equated in these sources with "big merchants," involved in the regional and supraregional trade networks, in loans and contracts for public works. Magistri (who were the equivalent of the artisti or the ministrali of other cities) were first and foremost artisans and professionals organized into guilds. Broadly speaking, in this period we may say that the city council, although no rule expressly stated as much, was composed of the above groups, or, in other words, as we have seen, of those who were able to contribute to taxation. Separated off in some fashion, or so it would seem, was the popolo, a fluid category also including salaried labourers and small artisans, whose physiognomy appears entirely in a "negative" form, since it refers to those labourers who cannot be listed among the magistri and who are not "habili" for a contribution. ${ }^{59}$

The above classificatory scheme is encountered throughout Sicily. ${ }^{60}$ The communities, large and small, in the royal demesne thus employed the same institutional language, that is to say, a shared nucleus of rules and of mechanisms, within a highly visible context of communication and of imitation. But the local use of these terms is highly nuanced, and this reveals the great variety of social contexts or of factional roles to which they alluded. For example, in many cities, the popolo had a place in the formal arena of political competition; in Palermo, however, it was excluded from it (at any rate after the uprising of 1450, in which it had been a

59 Ibid., pp. 50-61.

60 Epstein, An Island to Itself, pp. 357-366; Titone, Governments, pp. 175-80. 
protagonist). And there is still no doubt that the social profile of the powerful Palermitan gentlemen can hardly be made to correspond with the far less powerful groups we find elsewhere, with the same term being used (or that of curiali), at the summit of the local hierarchy.

We are thus concerned with a stereotyped vocabulary which serves to mask local differences and reflects the tendency of political and administrative language to represent in a simplified guise the complex realities of the demesnial space: the designated groups are not (and will not become) juridically delimited spheres, and not all the designations have the same descriptive efficacy. For example, whereas "magistri" implies the presence of guilds in the public arena, "gentilomini" or "borgesi" are still vague expressions.

By spelling out the forms assumed by such differences, we are also able to discern a new hierarchical logic: it is plain that the revolt of 1450 served to emphasise the separation between an aristocracy represented in the first place (but not solely) by the gentlemen and the rest of society. Yet the process was complex, as a threefold statement can elucidate. It was complex, first of all, in the eyes of contemporaries, who, lacking reliable classificatory grids, were attempting to equip themselves with compasses (the abovementioned designations), which historians then stumble upon. Secondly, the process was complex on account of the temporal stratification of the changes that had occurred. In other words, we must distinguish between, on the one hand, a dynamic pertaining to the longue durée, which started at the end of the 13th century, and, on the other, a discontinuity introduced in 1392 when royal authority was restored. It is this latter which in all probability precludes our backdating the schema under review. If, in other words, we go backwards, to the end of the 14th century, or a little further, this schema seems invisible, and its use proves to be concretely impossible. After four decades of seigneurial hegemony the restoration imparted new life to the self-government of the communities within the demesne, and a resumption of the structuring of the local political space and its actors. For example, it was with the advent of the Martins, and not before, that the representatives of the demesnial cities were called upon to participate in genuine parliamentary assemblies.

Finally, the third reason for the complexity of the process may be phrased as follows: the tendency we encounter in Palermo for social differences to be defined forms part of a more general phenomenon, common to the whole kingdom, to its cities, great and small, but also to the regional political society, divided between the court, the central offices and the management of the great fiefs. The quadripartite map with which 
we started simplifies the local roles but it is not the result of an abstract or scholastic reading of society; rather, it is a direct implication of a general political shift, that is to say, the need to define in some way the faces of the collective actors present on the various political stages. ${ }^{61}$

The biographical plane does not really correspond to these representations. If we restrict ourselves to the segment that has been most closely studied, that of the dominant groups, it confirms something that we already know, namely, the complex profile of the individuals and of their families. It is probable that individuals assume multiple signs of recognition, that their identities are composite, and that they therefore act at one and the same time on the plane of economic initiative (merchants, bankers, great agricultural entrepreneurs etc.), on that of political and administrative activity (as city officials or officials in the central offices), and on that of managing prestigious resources (such as the fiefs) granted to them by the crown. ${ }^{62}$ There is therefore not yet an exclusive index of belonging to the "nobility" (there is not, for example, a list of privileged families, as may occur elsewhere); and in this regard the rank of miles continues to be open, in some way implicit in any experience whatsoever of social advancement, but also, precisely because implicit, rendered banal, as a marker ex post facto of an authority already acquired in practice.

Confirming that the aristocratic sphere was an open one does, however, not mean that the actors did not seek to identify a boundary, within a more general tendency to recognise more or less new distinctions. The major distinctions, the ones that divide the whole social body, are more effective if they are accompanied by others which identify factions or families. In the $15^{\text {th }}$ century the signs of the dynastic structuration of families are far more obvious than before, and the programmes for safeguarding not only an inheritance but also the identity and memory (often recent) of the lineage appear more precise. ${ }^{63}$

By the same token, it is now easier to discern in the city the actions of opposed factions, in some cases clearly composed of families. A particularly telling example is the enmity in the 1420 s between the faction headed by the Crispo, a group of bureaucrats and fief-holders originally

61 Mineo, Nobiltà, pp. 184-291.

62 Cf. Vincenzo D’Alessandro, "Per una storia della società siciliana alla fine del Medioevo: feudatari, patrizi, borghesi," Archivio storico per la Sicilia orientale 77 (1981), 193-208; numerous profiles may be found in Tripoli, Amministrazione cittadina, pp. 167-222.

63 Mineo, Nobiltà, VII cap. 
from Messina, and that led by the Bononia, another family recently risen to prominence. The peace of 1425 allows us a glimpse of how the factions were constituted: members of the two families alongside particular individuals (in some cases linked by marriage) and whole kinship groups, such as the Valguarnera (omnibus de Valguarnerio) allied to the Crispo. ${ }^{64}$

Other macroscopic signs of the tendency for new cleavages to occur, and of the aristocratization of the upper segment, are already familiar to us: the emergence of guild solidarities within the crafts is one of the most significant, indeed, it bears out the supposition that the process in question affects the whole society. But public recognition of the crafts was somewhat slow in coming, as we have already noted. When we see political space becoming structured as a space of competition between parts, the definite presence of artisans appears to be only intermittent. The city council is the site that reveals the new actors and their relative consistency. ${ }^{65}$ It is in fact an agency without a completely formal existence but with full decision-making powers, and which also sees the participation, from the early $15^{\text {th }}$ century, of subjects not drawn from the composite aristocracy we discussed above. In an assembly of 1406 "nobili, iudichi legisti et altri burgisi chitatini honorati" took part; at another, held in 1416, there were "nobili homini et homini comuni." 66 In 1442, when the rectors of the new Hospital were to be elected, the officers of the Universitas followed roughly the same logic: the choice fell on one representative of the "gentlemen," one of the merchants and one of the borgesi. ${ }^{67}$ Only when the conflict intensified did the artisans become visible, as in the phases preceding the revolt of 1450 , when on some occasions their participation in the council is well documented. ${ }^{68}$ The presence of the Crafts in the public arena was therefore a possibility but was still very weak and, in some significant circumstances, confirmed more through the polemical response to it than in any other way.

It is not easy to explain why the social structure of Palermo, like that of many Sicilian cities, was represented in the age of Martin and then, above all, in that of Alfonso, in a somewhat more structured fashion than

64 Tripoli, Amministrazione cittadina, pp. 172-79, and in particular pp. $173 \mathrm{ff}$.

65 On the councils see above all Fabrizio Titone, "Istituzioni e società urbane in Sicilia, 1392-1409", Società e storia 105 (2004), pp. 480-86; for Palermo in particular, Tripoli, Amministrazione cittadina, pp. 123-36 and Titone, "Il tumulto."

66 Tripoli, Amministrazione cittadina, p. 136.

67 Titone, "Il tumulto," p. 53 and note 27.

68 Ibid., p. 58 for an account of a council of 1449 . 
had been the case in the previous century. For brevity's sake I will limit myself here to two causes. The first is already well-known to us; indeed, it is one of the guiding threads running through this essay. The reference is, once again, to the expansion of the sphere of city self-government, and therefore to the institutional weight of the urban magistracies; the greater this weight became, the more concern was shown, as much by potentially interested subjects as by the crown, in defining the rules of access and the formal composition of the institutions in question. The second cause, closely linked to the first, reminds us that the Kingdom's resources chiefly derive from here, from the cities, where a good proportion, and certainly the economically most dynamic part, of the Kingdom's population lived. The clarification of the city's social structure is then also a consequence of fiscal policies, which were harsher, relatively speaking, under Alfonso the Magnanimous, and which forced the communities to produce, either by consensus or through conflict, more definite criteria for dividing up the tax burden. ${ }^{69}$

If we look now at three series of statutes approved in different years, we find some reference to many of the themes touched upon so far, and this should make it easier for us to identify a general schema for the processes of corporatization and construction of collective identities.

The first two series, approved by Alfonso the Magnanimous in 1448 and $1451,{ }^{70}$ provide a snapshot of the situation on the eve of, and at the conclusion of the revolt of $145^{\circ}$. The theme they share is that of access to local offices, which was now more rigidly disciplined, even through a novel use of the notion of citizenship, which, as we have seen, was traditionally highly flexible. In 1448 it was reasserted that "foreign persons," who were not legitimate citizens and who had not lived for a specified period of time in the city, could not become officials of the Universitas. Three years later, however, distinctions were proposed between different sorts of citizen. No foreigner, it was now written, could hold an office "unless he is a legitimate and native citizen, by birth or else through having married a Palermitan woman, or through a privilege, although having received it he has to have lived in the aforementioned city for five years running." With regard to already entrenched rules the criterion of a period of residence

69 The most convincing analysis is in Epstein, An Island to Itself, pp. 353-374, 390-397; Id., "Conflitti redistributivi, fisco e strutture sociali (1392-1516)", in Francesco Benigno and Claudio Torrisi, eds., Élites e potere in Sicilia dal medioevo a oggi (Catanzaro-Rome, 1995), pp. $3^{1-45}$.

70 De Vio, Privilegia, pp. 306-324. 
of five years had introduced — perhaps originally in $1421^{71}$ —an important novelty, which would then be confirmed in $146 \mathrm{o}^{72}$, bearing witness to the consolidation of the influence of the urban magistracies.

It was then decided that the catapans or maestri di piazza should be "eminent and sober citizens, men of authority, and opulent" (notabili chitatini, gravi e di grandi auctoritate et opulenti), and not "men who were common, and ignorant of the usages and customs." This confirms the fact that access to the magistracies was broadened in the age of Alfonso, and that it was possible for exponents from the world of the small merchants and the artisans to participate in some of them, at any rate in those (such as the maestri di piazza or catapans) where matters of concern to them were addressed; but they also state that this broadening led to heightened tensions, which would lead to the uprising of 1450 .

This latter left its mark on another series of statutes, dating from 1451. Here we see the Universitas asking the King not to instigate proceedings against all those who, directly or indirectly, had taken part in the revolt. It therefore offered its assurance "that the most eminent men (princhipali), both officers and gentlemen and many other citizens and borgesi, who ordinarily make up and represent the universitas, did not take part in the recent uprising and had not assented to it." What is significant here is the explication of the idea that the duty of representing the universitas is entrusted to the "principali homini," a category restricted to city officials, gentlemen and borgesi. Not only were the artisans not included but, as we have already seen, a brutal attempt was made in the immediate aftermath of the revolt to exclude them from offices.

Twenty years later, the statutes approved by John II in $1472^{73}$ offer an analytic picture of the changes that had occurred in the course of the preceding decades, giving the impression of an adjustment to the operational logic of local politics.

The city asked ${ }^{74}$ that all officials be elected, as tradition dictated, "per scarfias," that is, by the drawing of lots once a list had been compiled of those who were eligible (the scrutiny). It is important to emphasise that the King's reply was not encouraging, and that the viceroy was asked from then on to make a choice from amongst those whose names were on the ballot, as if to confirm the importance that the magistracies had assumed

\footnotetext{
71 ASP, Protonotaro, 24, ff. 501v-508v (in Tripoli, Amministrazione cittadina, p. 27).

72 De Vio, Privilegia, p. 346.

73 Ibid., pp. 382-391.

74 Ibid., pp. 386-388.
} 
in the political balances of the Kingdom. ${ }^{75}$ The administrative sphere considered as a whole had expanded somewhat, and there were three times as many officials as there had been in the early 14th century. The flowchart now presupposed the following officers: the Praetor; 6 juristi judges ( 3 of them for the capitanial court and 3 for the appellate court); 6 idioti judges; 12 jurats; 12 maestri di piazza; 12 maestri di sciurta (night policemen); 6 master notaries of the capitanial court; 3 master notaries of the appellate court; 4 treasurers. Government personnel now numbered close on 60 , whereas, by way of contrast, in the 1320 s there were only 20 or so elected officials (in a city that then had twice as many inhabitants).

Given this composition, access to the above offices was now regulated in a socially more defined manner. Family membership really started to count $^{76}$ : father and son could not enter the same ballot, nor could two brothers (though the King would amend this, specifying that a father and son, or two brothers, could enter the same ballot but not serve as officers in the same year). The public role of the crafts had been recognized once and for all, and clearly delimited; at the same time, a polarisation between honourable and "vile" crafts emerges, and consequently the stance evident in the old article 77 of the customs was definitively superceded: ruffians, inn-keepers, butchers "et altri vili et dejecti persuni" could no longer stand for office as maestro di sciurta. ${ }^{77}$ Above all, neither "mekanichi ne artisti" could be considered for the office of idiota judge or maestro di piazza, since such offices were the exclusive preserve of gentlemen, lawyers "and honourable citizens." ${ }^{\text {" }}$ The field of pre-eminence and its boundaries were thus settled; guilds and artisans may not have been cut off from political society but they certainly were excluded from the most important offices. One of the aspects of the complex aristocratic dimension of Palermo now coincided not with the administration as such of the city but with its upper segment.

75 See Valentina Vigiano, L'esercizio della politica. La città di Palermo nel Cinquecento (Rome, 2004), pp. $115 \mathrm{ff}$.

76 De Vio, Privilegia, p. 388.

77 Ibid., p. 388.

78 Ibid., p. 389 . 


\section{CONCLUSIONS}

In this same span of years, extending from the death of Alfonso the Magnanimous, in 1458 , to the statutes of 1472 , the face of the city was changing. Some urbanistic interventions conferred new signs of recognition upon it and sanctioned the shifting of its epicentre northwards and towards the sea. Under this heading one might include the rebuilding, at the instigation of the praetor Pietro Speciale, of the praetorian palace, the political heart of the Universitas; the building of the new Archbishop's Palace with the complete reconstruction of the area around the Cathedral (and thus the creation of the largest square in all Palermo); and, finally, the creation "de lu planu de la Marina" opposite the Steri, the new and towering symbol of royal power. ${ }^{79}$

There were in this very same period new developments in the sphere of representation and memory. We have cause to refer once again here to the praetor Pietro Speciale, who, between 1469 and 1470, ordained that all the city's laws be collected and recorded in two magnificent illuminated codices. ${ }^{80}$ The following year, the Dominican and humanist Pietro Ranzano decided to publish separately, and in the vulgar tongue, a section from Book XXIX of his Annales omnium temporum, in other words, the pages he had dedicated to Palermo, entitled De autore, primordii et progressu felicis urbis Panhormi. ${ }^{81}$

We know that up until then the city had not had an official memoir: not since the days of Ibn Hawqal, or the Epistle of the pseudo-Falcando, and therefore not since the 12th century, had Palermo been so lovingly described and idealised. ${ }^{82}$ There was therefore something absolutely original about the work of Ranzano, himself a native of Palermo. It was no accident that he chose to begin with the acknowledgement of this void, which Ranzano endeavoured to fill. As it turned out, however, the Palermitan

79 Henri Bresc, "L'espace publique à Palerme (1100-1460)," in Jacques Heers, ed., Fortifications, portes de villes, places publiques, dans le monde méditerranéen (Paris, 1985), pp. 41-58, Vincenzo D'Alessandro, "Palermo aragonese," in Storia di Palermo, IV, Dal Vespro a Ferdinando il Cattolico (Palermo, 2008), pp. 118-125.

80 The codex of the privileges is kept in the Biblioteca comunale di Palermo (Qq H 125); that of the customs is in Cambridge University Library, see Paul Binski and Patrick Zutshi, eds., Western Illuminated Manuscripts, A Catalogue of the Collection in Cambridge University Library (Cambridge, 2011), pp. 431ff.

81 Pietro Ransano, Delle origini e vicende di Palermo, ed. Gioacchino Di Marzo (Palermo, 1864); cfr. Marzia Privitera, "Lotta politica e storiografia nella Sicilia di Giovanni II: Pietro Ranzano e l'opuscolo sulle origini di Palermo (1470-71)," Clio 32 (1996), 437-77.

82 Pezzini, “Articolazioni territoriali," p. 734, n. 16. 
humanist simply produced a rapid sketch chiefly concerned with the remote past, and with the distant, that is Phoenician, origins of the city, up until the Roman period. His account then swiftly traversed the Muslim conquest (a few lines), the Norman reconquest, and the dynastic arc of the titulars of the royal crown from Roger II to Manfred. At this point Ranzano's narrative broke off (though there is a reference to the circuit of walls planned by Manfred III Chiaromonte).

Two aspects are brought out in Ranzano's discourse about Palermo. First of all, the city's remote origins serve to root the autonomy of the Palermitan popolo in a free zone, but its meaning becomes more precise during the centuries marked by the predominance of republican Rome. There thus emerges the image of a "city confederated rather than subdued," 83 together with the predictable Roman origins of the office of Praetor, an office of highest rank in the kingdom, reserved "for those whom today we call Knights." ${ }^{4}$ The problem was that of Palermo's political status, a theme having to do with the regional and Mediterranean role of the modern city and one of the utmost topicality at a time when, at the end of the civil war in Catalonia, a new and more centralized order was taking shape in the system of the Aragonese kingdoms. The claim of the people of Palermo to be of higher rank alluded to the capacity of its political class to engage directly in a dialogue with the Crown, without the mediation of the Viceroy. This brings us to the second aspect. The people in question is the community represented by an aristocracy whose praises Ranzano sang, and which embodied the new identity of the modern city, an aristocracy which did not have roots in the 14th century (which can therefore be wholly disregarded), nor even in the Vespers, but in events coming after 1392. ${ }^{85}$ Ranzano's description of the new urban space, with its monuments and with the more recent alterations to the fabric of the city, was thus interwoven with an apology for the ruling class. In reality, however, the entire society had assumed a more clear-cut form, and a hierarchical order destined to prevail. Ranzano's work reflected this reality, which is why it appears to be an important symptom of the consolidation of a new urban identity.

\footnotetext{
83 Privitera, "Lotta politica," pp. $463 \mathrm{ff}$.

84 Ransano, Delle origini, p. 76.

85 Privitera, "Lotta politica," pp. 469-75.
} 